BACKGROUND: The mechanisms leading to hepatic injury in chronic hepatitis C virus (HCV) infection are only incompletely understood. Recent data propose a correlation of the intrahepatic expression of the CC chemokine RANTES and the degree of periportal and portal inflammatory liver damage.

Aim: Here, we have studied the intrahepatic mRNA levels of CC chemokines RANTES together with that

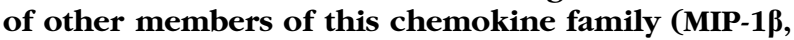
MCP-1, and MCP-2) in chronic hepatitis $C$ as compared with healthy controls.

Methods: Liver samples from $22 \mathrm{HCV}$-infected patients, nine individuals with primary biliary cirrhosis and from 12 normal controls were included into this study. Intrahepatic mRNA levels of CC chemokines RANTES, MIP-1 $\beta$, MCP-1, and MCP-2 were analyzed by a semi-quantitative reverse transcription/real-time polymerase chain reaction assay.

Results: In chronic HCV infection, intrahepatic RANTES mRNA levels were significantly higher than in non-infected controls (7.2-fold, $p<0.001)$ or in the disease control group $(2.8$-fold, $p<0.001)$ and higher levels of RANTES mRNA levels were observed in livers with an advanced stage of liver cell injury (histologic activity index $\geq 6$ ), although this difference was not statistically significant $(p=0.08)$. In contrast, mRNA levels of MIP-1 $(p=0.021)$ and MCP-1 $(p=0.021)$ were significantly lower in HCV liver samples while MCP-2 expression was similar in all groups analyzed. Conclusion: The data support the concept of chemokines as mediators of liver cell injury in chronic hepatitis $C$.

Key words: Hepatitis C, Intrahepatic chemokines, Real time polymerase chain reaction, Reverse transcription, Inflammation

\section{Semiquantitative analysis of intrahepatic CC-chemokine mRNAs in chronic hepatitis $C^{*}$}

\author{
Hans Dieter Nischalke ${ }^{1}$, Jacob Nattermann ${ }^{1}$, Hans- \\ Peter Fischer ${ }^{2}$, Tilman Sauerbruch ${ }^{1}$, \\ Ulrich Spengler ${ }^{1}$ and Franz Ludwig Dumoulin ${ }^{\mathrm{CA}}$
}

${ }^{1}$ Department of Internal Medicine I, and ${ }^{2}$ Department of Pathology, University of Bonn, Bonn, Germany

\author{
${ }^{\mathrm{CA}}$ Corresponding Author \\ Tel: +492282875507 \\ Fax: +492282874323 \\ E-mail: dumoulin@uni-bonn.de
}

Hepatitis C virus (HCV) leads to persistent infection in the majority of patients, with possible consequences of chronic liver disease progressing to liver fibrosis, cirrhosis and/or hepatocellular carcinoma. ${ }^{1}$ The mechanisms of tissue damage in chronic HCV infection are not completely understood. There is, however, increasing evidence that tissue damage might be the consequence of an ongoing intrahepatic antiviral immune response. $\mathrm{T}$ lymphocytes are regarded as the main cell population infiltrating the areas of liver damage leading to periportal necrosis. ${ }^{2,3}$ Migration of $\mathrm{T}$ lymphocytes critically depends on the local production of chemotactic cytokines, called chemokines, within inflamed tissues. ${ }^{4}$ The subgroup of CC chemokines comprises RANTES (regulated on activation, normally $\mathrm{T}$ cell-expressed and secreted), MIP-1 $\beta$, MCP-1 and, MCP2, which show chemotactic activity preferentially for T cells. ${ }^{5}$ Importantly, intrahepatic production of RANTES has

* Hans Dieter Nischalke, Jacob Nattermann and Hans-Peter Fischer contributed equally to this work been suggested to be involved in the progression of chronic hepatitis $\mathrm{C}$ to advanced forms of liver disease. ${ }^{2,3,6}$ Here, we have investigated the intrahepatic mRNA levels of the CC chemokines MIP-1 $\beta$, MCP1, MCP2 and RANTES in a total of 45 liver specimens from three groups: group 1, chronic HCV infection ( $n=22$; patient characteristics presented in Table 1); group 2, disease control $(n=9$ : patients with primary biliary cirrhosis according to internationally accepted criteria including antimitochondrial antibodies and liver histology REF); group 3, normal controls ( $n=12$; donor liver at the time of hepatectomy/unaffected areas from liver resection for secondary hepatic malignancy).

Determination of intrahepatic chemokine mRNA levels was carried out with a previously described semi-quantitative reverse transcription/real-time polymerase chain reaction assay. ${ }^{7}$ The study was approved by the local ethics committee and conformed with the ethical guidelines of the 1975 Declaration of Helsinki. Informed consent was ob- 
Table 1. HCV patient characteristics

\begin{tabular}{|c|c|}
\hline Median age (range) & $\begin{array}{c}38 \text { years } \\
(22-68 \text { years })\end{array}$ \\
\hline $\begin{array}{l}\text { Gender } \\
\text { Male } \\
\text { Female }\end{array}$ & $\begin{array}{r}15 \\
7\end{array}$ \\
\hline $\begin{array}{l}\text { Risk factor } \\
\text { Transfusion } \\
\text { Intravenous drug users } \\
\text { Hemophilia } \\
\text { Unknown }\end{array}$ & $\begin{array}{l}8 \\
4 \\
1 \\
9\end{array}$ \\
\hline $\begin{array}{l}\text { Genotype* } \\
\quad 1 \\
2 \\
3 \\
\text { Mixed/not typable } \\
\text { Viral load mean }\end{array}$ & $\begin{array}{c}12 \\
2 \\
4 \\
4 \\
1,453,795 \text { copies } / \mathrm{ml}\end{array}$ \\
\hline (standard deviation) ${ }^{\dagger}$ & $( \pm 1,736,889)$ \\
\hline $\begin{array}{l}\text { Median histological activit } \\
\text { Inflammation } \\
\text { Fibrosis } \\
\text { Total score }\end{array}$ & $\begin{array}{l}\text { range) } \\
4 \text { points }(1-9) \\
1 \text { point }(0-5) \\
5 \text { points }(1-12)\end{array}$ \\
\hline
\end{tabular}

* Inno-Lipa HCV II line probe assay (Innogenetics, Zwijndrecht, Belgium).

Amplicor HCV Monitor (Roche Diagnostic Systems, Branchburgh, USA).

tained from all patients. Briefly, total RNA was isolated from snap-frozen liver specimens (Trizol

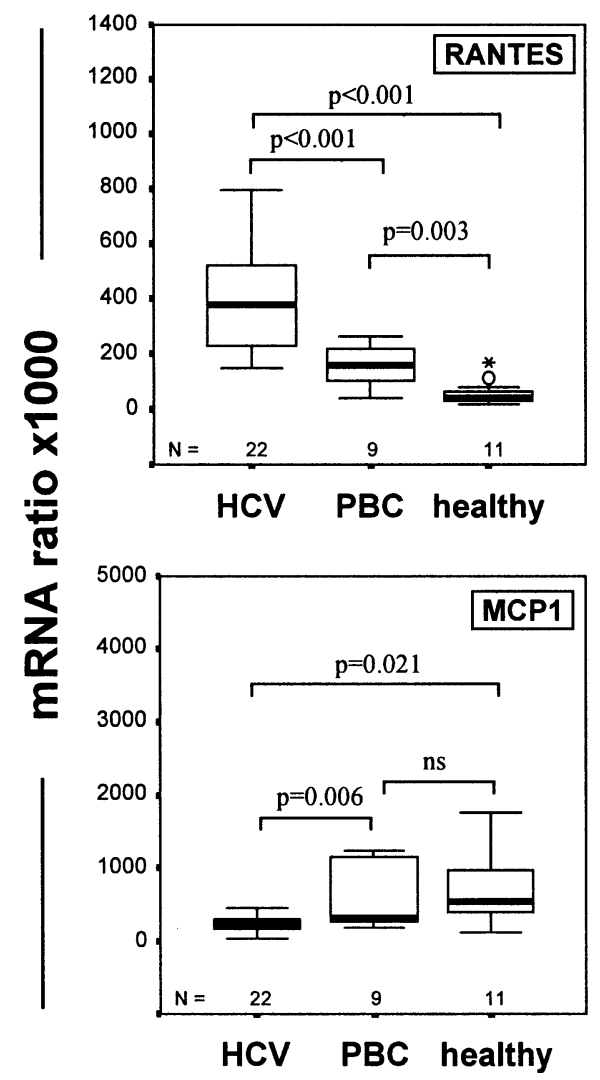

reagent; Life Technologies, Eggenstein, Germany) and $1 \mu \mathrm{g}$ was reverse transcribed for $45 \mathrm{~min}$ at $42^{\circ} \mathrm{C}$ and for $30 \mathrm{~min}$ at $55^{\circ} \mathrm{C}$ using $0.5 \mu \mathrm{g}$ of random hexamer primers (Promega, Heidelberg, Germany) and 200 units of Superscript Plus RT (Life Technologies, Eggenstein, Germany). For semiquantitative analysis of chemokine mRNA levels, samples were prepared in a final volume of $10 \mu \mathrm{l}$, containing $1 \mu \mathrm{l}$ of either external standards or cDNA equivalent to $20 \mathrm{ng}$ of total RNA, $1 \mu \mathrm{l}$ of LightCycler FastStart DNA Master SYBR Green I Mix (Roche Molecular Biochemicals, Mannheim, Germany), $3.5 \mathrm{mM} \mathrm{MgCl}$ and $0.5 \mu \mathrm{M}$ of each of the following primers (Tib MolBiol, Berlin, Germany): RANTES, 5'-acc aca ccc tgc tgc tt gc-3' (forward) and $5^{\prime}$-ccg aac cca ttt ctt ctc tgg- $3^{\prime}$ (reverse); MIP-1 $\beta, 5^{\prime}$-acc ctc cca ccg cet gct gc- $3^{\prime}$ (forward) and $5^{\prime}$-gtt gca ggt cat aca cgt act cc-3' (reverse); MCP-1, 5'gat ctc agt gca gag gct cg-3' (forward) and $5^{\prime}$-tgc ttg tcc agg tgg tcc at- $3^{\prime}$ (reverse); MCP-2, 5'-atg ctg aag ctc aca ccc ttg ccc-3' (forward) and $5^{\prime}$-cag atg ctt cat gga atc cct gac c-3' (reverse). The thermal profile settings were as follows: initial denaturation ( $7 \mathrm{~min} /$ $95^{\circ} \mathrm{C}$ ), followed by 35 amplification cycles: $3 \mathrm{sec} /$ $65^{\circ} \mathrm{C}\left(\beta\right.$-actin, $\left.60^{\circ} \mathrm{C}\right) ; 15 \mathrm{sec} / 72^{\circ} \mathrm{C}(\beta$-actin, $30 \mathrm{sec})$;
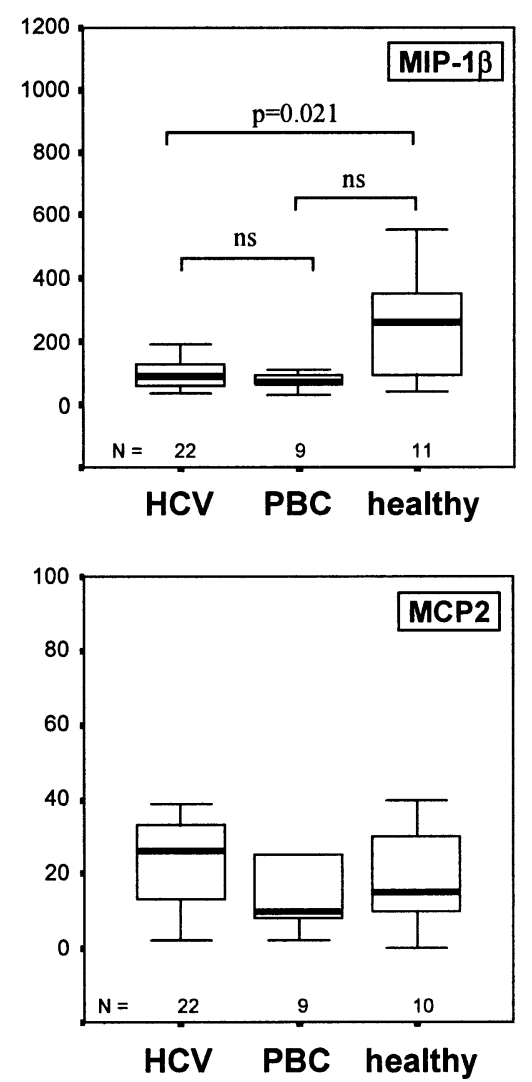

FIG. 1. Semiquantitative determination of intrahepatic steady-state mRNA levels in HCV infection. CC chemokine mRNA levels were detemined in liver specimens from patients with chronic hepatitis $C(n=22), \operatorname{PBC}(n=9)$ and normal controls $(n=12)$. Results of semiquantitative determination of intrahepatic steady-state mRNA levels of RANTES (upper left), MIP-1 $\beta$ (upper right), MCP1 (lower left), and MCP2 (lower right) in liver specimens from patients with chronic hepatitis C ( $n=22)$, primary biliary cirrhosis $(n=9)$ and normal controls $(n=12)$. As shown we found significantly increased levels of RANTES mRNA but decreased levels of MIP-1 $\beta$ and MCP1 in livers from HCV-infected patients as compared with the control groups. Data presented as boxplots showing median, quartiles and extreme values; $p$ values presented as calculated with Mann-Whitney U-test. 
0 sec $/ 95^{\circ} \mathrm{C}$ followed by melting curve analysis (increasing temperature from $60-95^{\circ} \mathrm{C}$ ). Acquisition temperature for the fluorescence signal was adjusted to $85^{\circ} \mathrm{C}\left(\beta\right.$-actin, RANTES, MIP1 $\beta$ ) or $84^{\circ} \mathrm{C}$ (MCP- 1 , MCP2), respectively. Results were standardized with respect to mRNA levels of the housekeeping gene $\beta$-actin measured with primers for $5^{\prime}$-cgg gaa atc gtg cgt gac at-3' (sense) and 5'-gaa ctt tgg ggg atg ctc gc$3^{\prime}$ (antisense). A multi-specific competitor fragment was used as external standard. ${ }^{7,8}$

In confirmation of preliminary data, ${ }^{7}$ we observed markedly lower intrahepatic MIP-1 $\beta$ and MCP-1 mRNA levels in HCV-infected patients than in controls (Fig. 1) while MCP-2 mRNA levels were similar in the three groups studied (Fig. 1). In contrast, we found significantly higher intrahepatic RANTES mRNA levels in specimens from chronic hepatitis C than in normal controls $(7.2$-fold, $p<0.001)$ or in the disease control group (2.8-fold, $p<0.001$; Fig. 1). Investigating a possible correlation with clinical, laboratory or virological data we found that liver samples with a more severe degree of intrahepatic inflammation (histologic activity index $\geq 6$ ) showed a trend towards higher RANTES mRNA levels $(p=0.08)$, while no significant correlation was found between intrahepatic chemokine mRNA levels and patient characteristics (age, risk factor) or characteristics of viral infection (viral load or genotype; data not shown).

MCP-1 can be induced in many cell types including hepatocytes, Kupffer cells and stellate cells. ${ }^{9}$ The finding of lower intrahepatic MCP-1 mRNA levels are in contrast to a recent report on a trend towards increased intrahepatic MCP-1 mRNA levels in chronic HCV infection. ${ }^{3}$ This discrepancy could be due to differences in the composition of the patient population and/or methods of chemokine mRNA determination. Our data, however, fit well with reports on downregulation of MCP-1 expression by viral proteins. Thus, MCP-1 expression was downregulated in hepatitis $\mathrm{B}$ virus $\mathrm{X}$ protein transgenic cells ${ }^{10}$ and the activity of the MCP-1 gene promoter was inhibited by HCV core protein. ${ }^{11}$ It is therefore tempting to speculate that lower intrahepatic MCP-1 mRNA levels are the consequence of an interaction of $\mathrm{HCV}$ with the gene expression of host cells.

In line with previous reports ${ }^{3}$ we found higher intrahepatic RANTES mRNA levels in chronic hepatitis C. Moreover, it has been described that the enhanced expression of RANTES mRNA correlates to CD8 gene expression and to the extent of liver damage, suggesting that a release of proinflammatory cytokines by activated $\mathrm{T}$ cells contributes to immunemediated liver damage in hepatitis C. ${ }^{2,3,12}$ Again, in line with these observations, we observed a trend towards higher RANTES mRNA levels in liver samples with a more severe degree of intrahepatic inflammation. In addition, we could recently demonstrate that exposure of $\mathrm{CD}^{+} \mathrm{T}$ cells to HCV E2 results in an enhanced release of RANTES and an increase, albeit smaller, in RANTES mRNA. ${ }^{13}$ Alternatively, increased RANTES mRNA levels could be due to a direct interaction of HCV with the gene expression of the host cell that has been described for hepatic cell lines. $^{11}$

In summary, the data presented suggest distinct alterations of intrahepatic CC chemokine mRNA levels. While there is some evidence to suggest that this may be the result of an interaction of viral proteins with host cells, the significance of these alterations in the intrahepatic CC chemokine pattern for the pathogenesis of chronic hepatitis $\mathrm{C}$ virus infection remains to be elucidated.

ACKNOWLEDGEMENTS. The authors gratefully acknowledge their liver transplant surgeons for providing specimens. The work was supported by a Grant from the Faculty of Medicine, University of Bonn (Bonfor Programme, grant \# O-107.0063).

\section{References}

1. Flamm SL. Chronic hepatitis C virus infection. JAMA 2003; 289: 24132417.

2. Apolinario A, Majano PL, Alvarez-Perez E, Saez A, Lozano C, Vargas J, Garcia-Monzon C. Increased expression of $\mathrm{T}$ cell chemokines and their receptors in chronic hepatitis C: relationship with the histological activity of liver disease. Am J Gastroenterol 2002; 97: 2861-2870.

3. Leroy V, Vigan I, Mosnier JF, et al. Phenotypic and functional characterization of intrahepatic T lymphocytes during chronic hepatitis C. Hepatology 2003; 38: 829-841.

4. Sallusto F. The role of chemokine receptors in primary, effector and memory immune response. Exp Dermatol 2002; 11: 476-478.

5. Mackay CR. Chemokine receptors and T cell chemotaxis. J Exp Med 1996; 184: 799-802.

6. Bone-Larson CL, Simpson KJ, Colletti LM, et al. The role of chemokines in the immunopathology of the liver. Immunol Rev 2000; 177: 8-20.

7. Dumoulin FL, Nischalke HD, Leifeld L, von dem Bussche A, Rockstroh JK, Sauerbruch T, Spengler U. Semi-quantification of human C-C chemokine mRNAs with reverse transcription/real-time PCR using multi-specific standards. J Immunol Methods 2000; 241: 109-119.

8. Dumoulin FL, Altfeld M, Rockstroh JK, Leifeld L, Sauerbruch T, Spengler $\mathrm{U}$. Semiquantitation of human chemokine mRNA levels with a newly constructed multispecific competitor fragment. J Immunol Methods 1999; 224: 61-67.

9. Simpson KJ, Henderson NC, Bone-Larson CL, Lukacs NW, Hogaboam $\mathrm{CM}$, Kunkel SL. Chemokines in the pathogenesis of liver disease: so many players with poorly defined roles. Clin Sci (Lond) 2003; 104: 4763.

10. Agnello V, Abel G, Elfahal M, Knight GB, Zhang QX. Hepatitis C virus and other flaviviridae viruses enter cells via low density lipoprotein receptor. Proc Natl Acad Sci USA 1999; 96: 12766-12771.

11. Soo HM, Garzino-Demo A, Hong W, et al. Expression of a full-length hepatitis $\mathrm{C}$ virus CDNA up-regulates the expression of $\mathrm{CC}$ chemokines MCP-1 and RANTES. Virology 2002; 303: 253-277.

12. Fiore G, Angarano I, Caccetta L, Serrone M, Jirillo E, Schiraldi O, Antonaci S. In-situ immunophenotyping study of hepatic-infiltrating cytotoxic cells in chronic active hepatitis C. Eur J Gastroenterol Hepatol 1997; 9: 491-496.

13. Nattermann J, Nischalke H, Ahlenstiel G, Feldmann G, Sauerbruch T, Spengler U. Binding of the hepatitis $\mathrm{C}$ virus envelope $\mathrm{E} 2$ protein to CD81 results in reduced responsiveness of $\mathrm{CD}^{+}$lymphocytes to CC chemokines. J Hepatol 2004; 40: 408 .

\section{Received 16 April 2004}

Accepted 28 June 2004 


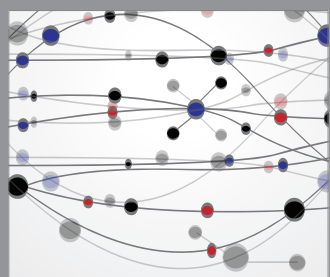

The Scientific World Journal
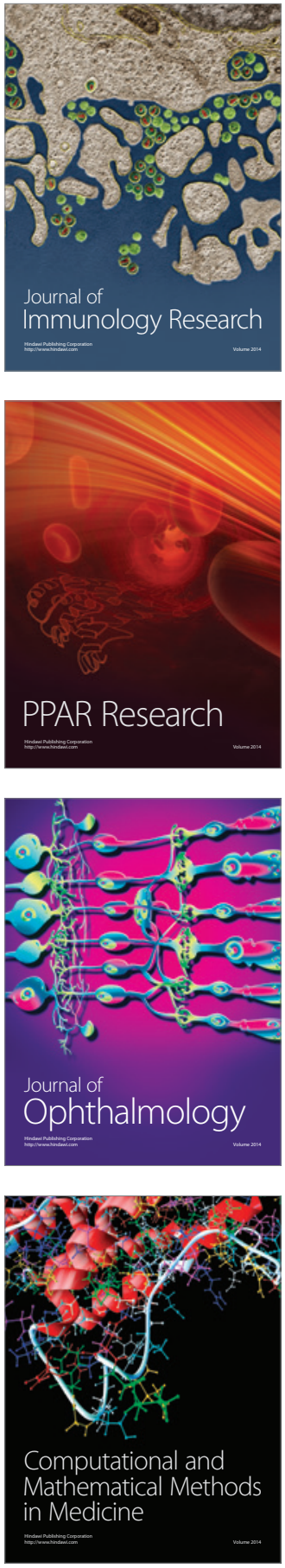

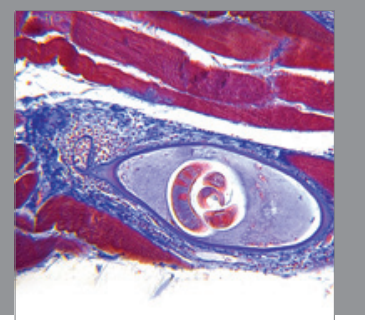

Gastroenterology

Research and Practice
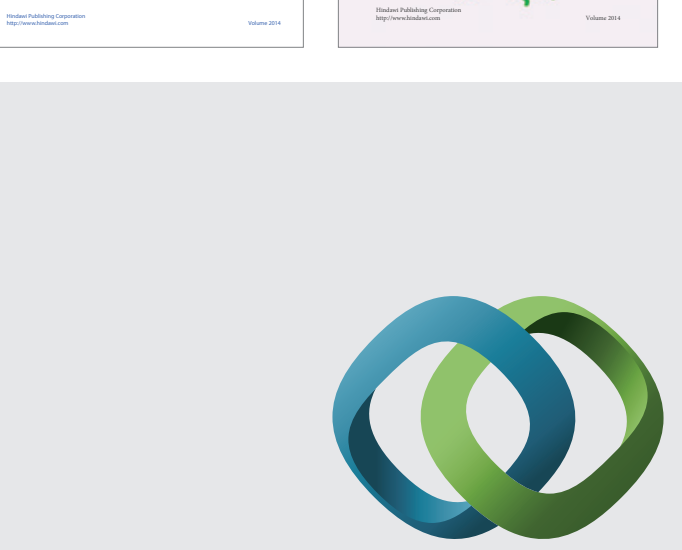

\section{Hindawi}

Submit your manuscripts at

http://www.hindawi.com
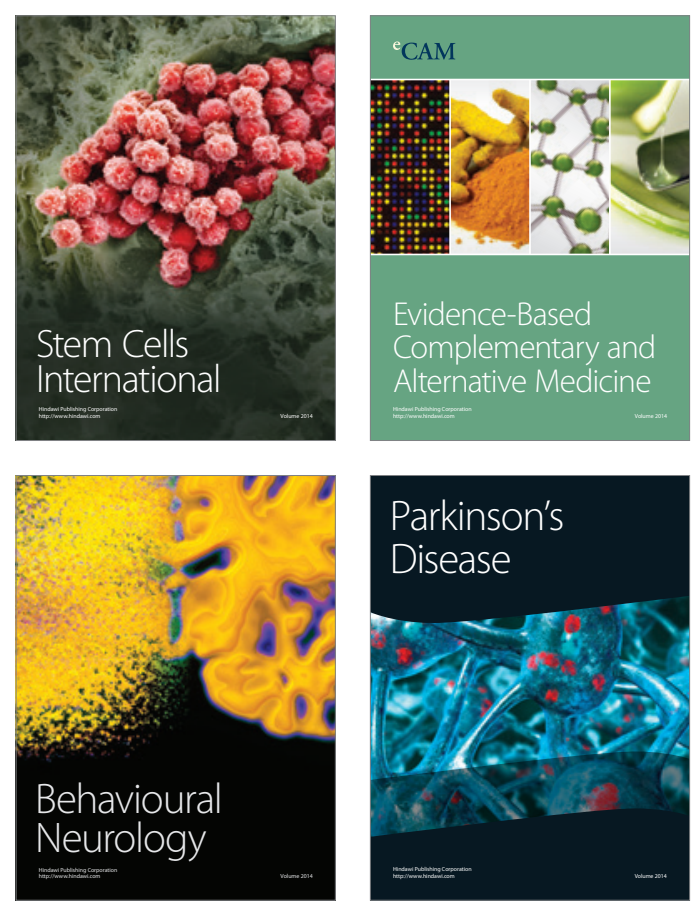

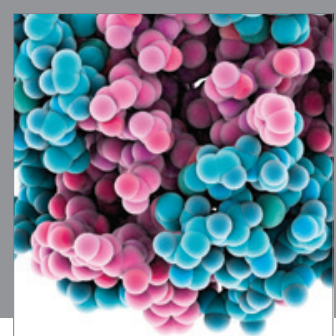

Journal of
Diabetes Research

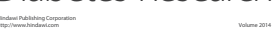

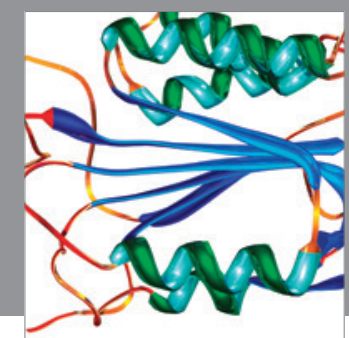

Disease Markers
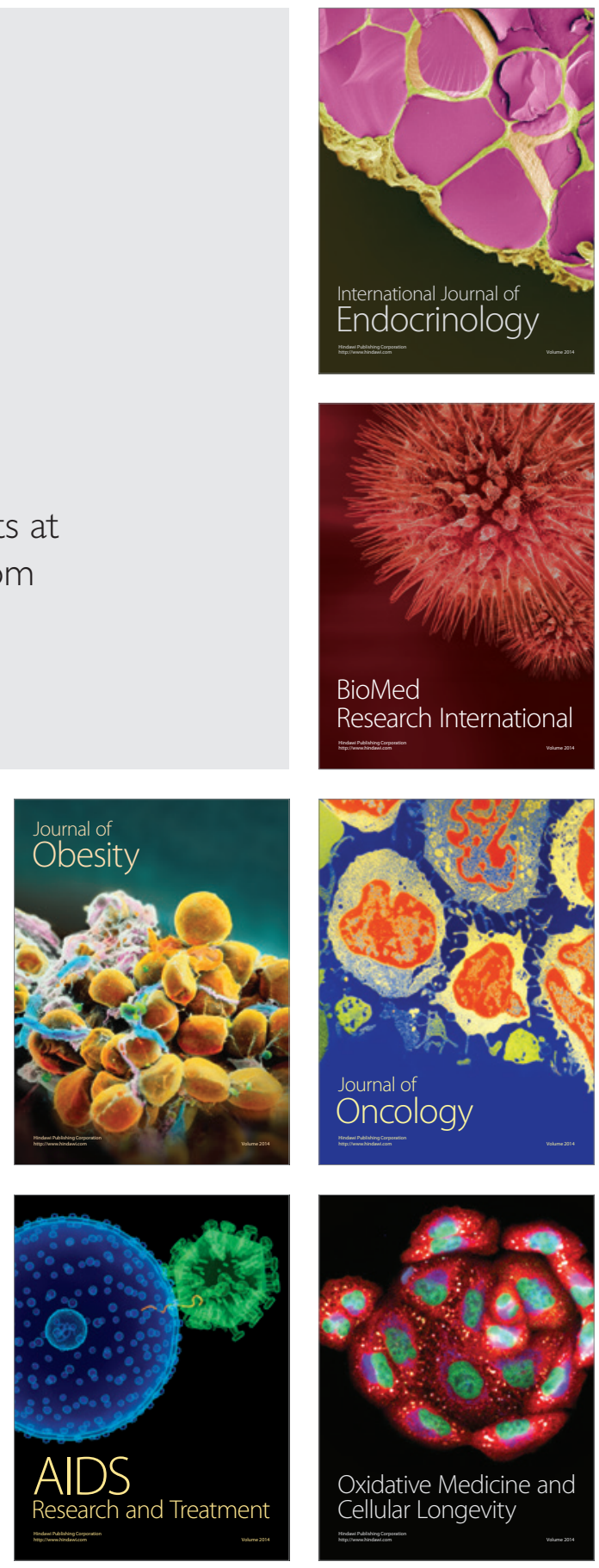